Based on the research results, optimization modeling was performed and the shelf life of pasteurized sausage products of the boiled group with the elements of active packaging was substantiated. Re-pasteurization was carried out at the temperature of 85-90 ${ }^{\circ} \mathrm{C}$ for $15-20$ minutes in the presence of an oxygen absorber. The dependence regarding the impact of indicators of peroxide and acid numbers on residual content of sodium nitrite accumulation during long-term storage, depending on the formulation composition of sausage products was found.

According to the data of stability of microbiological indicators of pasteurized sausage products and increased values of peroxide and acid numbers, the mathematical dependences to determine the shelf life of sausages were obtained. The dependences substantiate the extended storage for boiled sausage products of the first and topgrade under the condition of using the protective barrier multilayer polymeric materials and the elements of "active packaging".

The conducted optimization modeling in accordance with the obtained experimental data substantiates with high confidence probability the relations between the indicators of quality and safety of sausage products at their shelf life that is longer than normatively recommended. Due to the analysis of response surfaces, an extended shelf life of the high-grade pasteurized sausage products of the boiled group was estimated to be up to 95 days, of the first grade - up to 83 days. The obtained mathematical dependences make it possible to predict the shelf life of pasteurized boiled sausage products, depending on the formulation composition and the use of an oxygen absorber during pasteurization.

The presented prediction and substantiation of the shelf life was performed for sausages, the formulation of which contained the traditional kinds of meat: beef, pork, and poultry. In addition, poultry of mechanical rolling, protein stabilizer and animal proteins based on pig skins, dairy products and spices were included in the composition. In the process of production, sausages were subject to re-pasteurizing at the temperature of $85-90^{\circ} \mathrm{C}$ for $15-20$ minutes

Keywords: small sausages, pasteurization, storage, residual nitrite, peroxide peroxide value, acid value, microflora
UDC 637.5

DOI: $10.15587 / 1729-4061.2020 .209588$

\section{SUBSTANTIATING THE OPTIMIZED SHELF LIFE OF PASTEURIZED SAUSAGES WITH THE ELEMENTS OF ACTIVE PACKAGING}

V. Pasich n y i

Doctor of Technical Sciences, Professor, Head of Department Department of Technology of Meat and Meat Products* E-mail: Pasww1@ukr.net

O. Shevchenko Doctor of Technical Sciences, Professor, Vice Rector*

E-mail: tmipt@ukr.net

O. Khrapachov

Regional Represantative

LLC "Sirius Extrusion"

Pilotska str., 20, Khmelnitsky, Ukraine, 29010

E-mail:kov.pack@ukr.net

A. Mary ni n

$\mathrm{PhD}$, Associate Professor, Head of Laboratory Problem Scientific Research Laboratory* E-mail: andrii_marynin@ukr.net

I. Radzievskay a

$\mathrm{PhD}$, Associate Professor

Department of Fats, Perfumery and Cosmetic Products Technology* E-mail: logos2007@ukr.net

Y. Matsuk

$\mathrm{PhD}$, Associate Professor

Department of Food Technologies Oles Honchar Dnipro National University Haharina str., 72, Dnipro, Ukraine, 49010

E-mail: Iyly2006@ukr.net

A. G e r e d c h u k

$\mathrm{PhD}$, Senior Lecturer

Department of Food Industry Technologies and Restaurant Industry Poltava University of Economics and Trade Kovalia str., 3, Poltava, Ukraine, 36014

E-mail: alina-ger13@ukr.net

M. Ku ligin

Doctor of Technical Sciences, Associate Professor Department of Chemical Technology, Expertise and Food Safety Kherson National Technical University Beryslavske shosse str., 24, Kherson, Ukraine, 73008

E-mail: mkuligin@gmail.com

*National University of Food Technologies Volodumurska str., 68, Kyiv, Ukraine, 01601

\section{Introduction}

Modern trends in ensuring food quality and safety are focused on the development of standardized protocols of production organization. Besides, incoming control of raw materials, delivery, and sale of food products to trading networks, minimizing the risks regarding product safety for consumers remain important [1,2]. 
The basic principles of ensuring the safety of food, in particular, based on animal raw materials, rest on the identification of specific contaminant forms of microorganisms and their exposure to bacteriostatic substances [1,2]. The intensity of their accumulation in the storage process of meat products to a critical level is the main hazard in the consumption of these food products.

The shelf life of foodstuffs under the specified storage conditions [4] is determined by the achievement of the critical values of microbiological contamination, taking into consideration the reserve coefficient [3].

However, besides the maintenance of microbiological safety of products in their long-term storage itself, important quality and safety factors include the minimization of fat spoilage processes [5].

In the fat spoilage process, there is the accumulation of peroxide (PV) and acid value (AV) [6], the critical values of which determine the shelf life and safety of foodstuffs [7, 8].

Thus, the search for effective antioxidants and the use of barrier technologies [8], which slow down the accumulation of $\mathrm{PV}$ and $\mathrm{AV}$ in the processes of fat spoilage during the storage term, makes it possible to extend the shelf life of food products.

The influence of re-pasteurization on the PV and AV indicators for sausage products of different grades during longterm storage, including using the elements of active packing, was not studied. Research and studying the dynamics of changes in the PV and AV for pasteurized boiled sausages of different grades, with the extended shelf life, will enable prediction of the safety of these products. This research is relevant, as it allows the theoretical and practical prediction of the storage conditions of pasteurized boiled sausage products with the simultaneous use of an oxygen absorber.

\section{Literature review and problem statement}

The methods for extending the shelf life using pasteurization and sterilization effects have both definite advantages concerning the microflora inactivation, and a series of shortcomings, related to the changes in the quality composition of proteins and fats $[3,6,7]$. In the production of pasteurized boiled sausage products, the normal shelf life is 45 days $[3,4,8]$. To extend the shelf life of meat products, one uses top barrier packaging materials and the elements of active packaging, improving their storage conditions [4,5]. There is an evidence of a potential possibility of leveling the difference between pasteurization and sterilization effects [8] when it comes to the development of microflora. This creates the prospects of extension of the shelf life of sausage products. However, the systematization of the influence on changes in qualitative chemical composition, primarily lipids, while using re-pasteurization requires further research [3, 6, 7], including the use of antioxidants [2, 8, 9]. The substantiation of the shelf life requires systemic analysis and can be realized based on the analysis of experimental data of safety indicators of sausages, in which reliable factors of influence are raw materials and shelf life [9]. For sausage products of the boiled group, the impact of chemical composition, oleoresins of spices and extracts [10-13], the use of the systems of high-barrier active packaging [14, 15], for a longer period than that recommended by regulations $[2,8,9]$, were not studied. In addition, unconventional physical methods of influencing raw materials $[16,17]$ are used. Most research into sausage products in terms of their shelf life records the indicators of products without their mathematical analysis and prediction of the food chain safety.

Taking into account the background microbiological contamination in sausage products by the MAFAM level, in the presence of non-meat formulation components or a significant proportion of poultry meat in the composition of products $[2,8,18]$ requires further research. In addition, the use of poultry with the specific microflora, plant fillers [18-20], and milk processing products [21,22] as a part of pasteurized sausages was not studied completely.

Until now, there was no parametric analysis of the further accumulation of MAFAM during storage, changing particles of residual nitrite and kinetics of fat spoilage processes for sausages of boiled group in terms of storage, exceeding the normative.

Conducting such research using mathematical analysis will make it possible to widen the idea of the potential possibilities of their use for sausage products with a significant share of secondary animal raw materials $[23,24]$. It is also important to study the effect on the shelf life of non-protein fillers, including hydrocolloids, to prevent the syneresis effect during storage [25].

At high initial values of $a_{w}[26,27]$, the problem of influence of variation of pasteurization conditions on a change in acid value (AV) and peroxide value (PV) and the kinetics of MAFAM accumulation during the shelf life of more than 45 days was not studied [2, 28-30].

The study of the influence of "active packaging" on microbiological stability proves the effectiveness of the use of absorbers [31]. However, the available sources do not contain the data on the influence of the elements of "active packaging" on a change in PV and AV when they are used at the pasteurization stage.

Parametrization of dependences and detection of synergy effects using the elements of "active packaging" and re-pasteurization on the stability of physical-chemical and microbiological indicators of sausages with extended shelf life long of sausages require further research.

Statistical validity of these effects will subsequently predict the conditions for pasteurization and substantiate the rational shelf life for boiled sausage products for extended shelf life.

\section{The aim and objectives of the study}

The aim of this work was to study the influence of pasteurization with the element of "active packaging" - an oxygen absorber on a change in safety indicators of boiled sausage products with a combined composition of raw materials for the prediction of their shelf life.

According to the set aim, the following tasks were set:

- to determine the influence of pasteurization with an oxygen absorber on the residual content of sodium nitrite in the boiled sausage products in the process of storage and to assess the possible relations between the residual nitrate and the value of peroxide number;

- to study and determine the influence of pasteurization with and without the use of an oxygen absorber on a change in peroxide number of sausages of different grades with the shelf life of 45 days, which is longer than the normatively regulated period; 
- to determine the dynamics of a change in the acid number of sausages of different grades, pasteurized with and without the use of an oxygen absorber during the storage for 45 days, which is longer than the normatively regulated period;

- to explore and determine the influence of pasteurization with and without the use of an oxygen absorber on microbiological indicators of pasteurized sausages of top and first grades during extended shelf life.

\section{Materials and methods for studying sausages pasteurized with oxygen absorber during storage}

To optimize the shelf life of sausages, pasteurized with an oxygen absorber, top-grade sausages "Extra" and first-grade sausages "Delicious", which were produced by LTD "Zhytomyr meat processing plant" (Ukraine) by TU U 15.1-32122069006:2008, were studied [31].

The formulations of the studied products used the traditional types of meat raw materials (pork, poultry, beef, protein stabilizers, animal collagen-containing proteins), and spices [31].

The sausages, cooled to the temperature of $15^{\circ} \mathrm{C}$, were packed on the thermoforming lines "Multivac" (Germany) and "Webomatic" (Germany) by vacuum. They were packed into multi-layer polymer films produced by "Sirius Extrusion" LTD (Ukraine). The samples were packaged with and without sachet-packets of an oxygen absorber according to TU U 20.5-02070938-143:2013 produced by LTD "YUTAK" (Ukraine) and subjected to pasteurization.

Pasteurization was carried out in a thermochamber of the "Fessman" brand (Germany) at 85-90 ${ }^{\circ} \mathrm{C}$ for $15-20$ minutes. Obtained samples after cooling with water up to the temperature of $15{ }^{\circ} \mathrm{C}$, were additionally cooled to the temperature from 0 to $6{ }^{\circ} \mathrm{C}$.

The samples of pasteurized top and firstgrade sausages were stored under standard conditions at LTD "Zhytomyr meat processing factory" (Ukraine) and in parallel at the laboratory of the Problematic scientific research laboratory of the $\mathrm{Na}$ tional University of Food Technologies (Ukraine).

The study of microbiologic indicators and residual content of sodium nitrite was carried out in accordance with the requirements of TU U 15.1-32122069-006:2008 by the standard procedures. The number of MAFAM, CFO in $1 \mathrm{~g}$ was determined in accordance with DSTU ISO 48332:2014 "Microbiology of a food chain. Horizontal method for counting microorganisms" [30, 32, 33].

Preliminary fat extraction was carried out to analyze the sausages and determine their PV and AV. Computation of the PV and AV was performed according to traditional procedures [34].

Modeling and processing of the experimental data were performed using the Mathcad mathematical package and "Data Analysis" (ET) MS Excel.

Existing models of assessment of pasteurization impact on the indicators of sausages of different formulations were reduced to the task of regression analysis of experimental data with the help of package "Data Analysis" (ET) MS Excel and the method of multi-dimensional approximation by means of the Mathcad mathematical package.
To detect the dependences of a change in sodium nitrite on the AV, we used the methodology of response surface with the help of graphic 3D models.

In a general form, the response function is described by the following polynomial:

$$
\hat{y}(x, b)=b_{0}+\sum_{l=1}^{n} b_{1} x_{1}+\sum_{k=1}^{n} b_{k} x_{k}^{2}+\sum_{i=1}^{n-1} \sum_{j=i+1}^{n} b_{i j} x_{i} x_{j},
$$

where $x \in R^{n}$ is the vector of variables, $b$ is the vector of parameters.

To study the values of the AV of the sausages of different grades pasteurized with and without an oxygen absorber in the storage process, the approximation and prediction of the experimental data in the (EM) MS Excel environment using the trendline was performed.

The data of the experimental research are presented in Table 1.

Table 1

Data of experimental research

\begin{tabular}{|c|c|c|c|c|c|c|}
$\begin{array}{c}X_{1} \text {, shelf } \\
\text { life, days }\end{array}$ & $\begin{array}{c}X_{2}, \\
\text { starch, } \\
\%\end{array}$ & $\begin{array}{c}X_{3} \text {, net weight } \\
\text { of an oxygen } \\
\text { absorber, g }\end{array}$ & $\begin{array}{c}\text { Residual } \\
\text { sodium } \\
\text { nitrite, \% }\end{array}$ & $\begin{array}{c}\text { AV, mg } \\
\text { KOH/g } \\
\text { of fat }\end{array}$ & $\begin{array}{c}\text { PV, } \\
\text { mMol } \\
\text { AK }\end{array}$ & $\begin{array}{c}\text { MA- } \\
\text { FAM, } \\
\text { CFO in } \\
1 \mathrm{~g}\end{array}$ \\
\hline 1 & 0 & 0 & 0.0029 & 0 & 0 & 50 \\
\hline 1 & 3.12 & 0 & 0.0027 & 0 & 0 & 45 \\
\hline 1 & 0 & 2.5 & 0.0029 & 0 & 0 & 35 \\
\hline 1 & 3.15 & 2.5 & 0.0027 & 0 & 0 & 10 \\
\hline 35 & 0 & 0 & 0.0025 & 3.36 & 2.8 & 110 \\
\hline 35 & 3.12 & 0 & 0.0025 & 0.78 & 0 & 90 \\
\hline 35 & 0 & 2.5 & 0.0025 & 4.15 & 6.29 & 10 \\
\hline 35 & 3.15 & 2.5 & 0.0025 & 2.05 & 1.94 & 50 \\
\hline 65 & 0 & 0 & 0.0023 & 3.62 & 5.11 & 210 \\
\hline 65 & 3.12 & 0 & 0.0022 & 1.42 & 2.54 & 130 \\
\hline 65 & 0 & 2.5 & 0.0023 & 4.41 & 6.82 & 15 \\
\hline 65 & 3.15 & 2.5 & 0.0022 & 2.64 & 4.93 & 95 \\
\hline 94 & 0 & 0 & 0.0021 & 3.88 & 9.86 & 270 \\
\hline 94 & 3.12 & 0 & 0.0020 & 2.11 & 7.40 & 210 \\
\hline 94 & 0 & 2.5 & 0.0022 & 6.26 & 12.30 & 35 \\
\hline 94 & 3.15 & 2.5 & 0.0021 & 2.40 & 9.86 & 12 \\
\hline
\end{tabular}

Table 1 shows the results of the experimental research into the indicators of sausages during the storage process. The results of a change in crucial safety indicators of sausages in time made it possible to perform mathematical analysis of the influence of quantitative input variables to predict the shelf life.

\section{Determining the influence of pasteurization with an oxygen absorber on the indicators of sausage products during storage}

5. 1. The influence of pasteurization and the PV on residual content of nitrite during storage

According to the experimental data in Table 1 for the control samples of sausages and those that were re-pasteurized with and without the use of an oxygen absorber, the indicators that characterize the safety of products were 
determined. Emphasis was placed on a change in the process of storage of residual content of sodium nitrite, the values of acid and peroxide numbers, and the level of microbiological contamination of sausages.

Fig. 1 contains averaged data on the residual content of sodium nitrite in the process of storing the sausages with and without an oxygen absorber.

Fig. 1 shows the absence of a significant difference in the kinetics of a decrease in residual content of sodium nitrite with and without an oxygen absorber up to 65 days of storage.
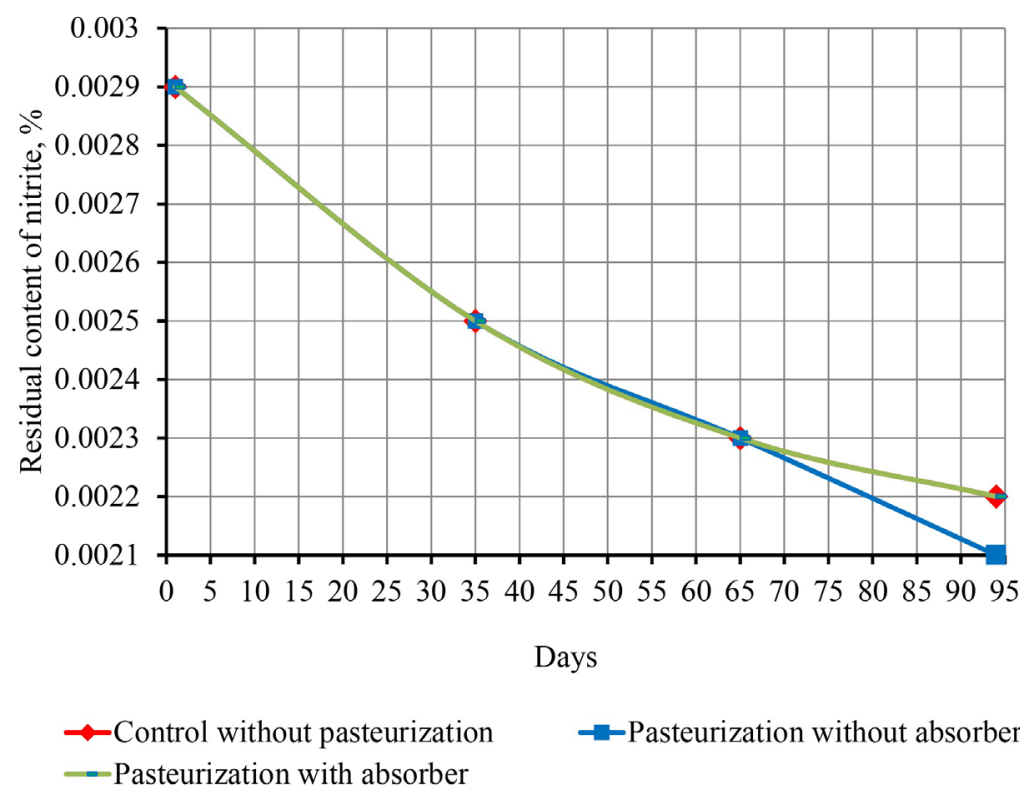

- -Pasteurization without absorber

Fig. 1. Change in residual nitrite in the process of storage of pasteurized sausages with and without oxygen absorber

During the storage of pasteurized boiled sausage products, the proportion of sodium nitrite decreases, which may be associated with an increase in the PV values during the storage.

A change in sodium nitrite in the formulations was modeled by the influence of quantitative input variables (peroxide number and the shelf life in given ranges).

The nature of the distribution of the experimental points in factorial space indicates that the dependence may have the form of a polynomial of second degree (Table 1).

$$
Z=b_{0}+b_{1} X+b_{11} X^{2}+b_{2} Y+b_{22} Y^{2}+b_{12} X Y,
$$

where $b$ is the constant; $X$ is the peroxide number, $\mathrm{mMol} \mathrm{AK}, \%$; $Y$ is the shelf life, days.

To assess unknown parameters $b_{0}, b_{1}, b_{2}$, the leastsquares method (LSM) was applied. According to this method, the unknown parameters of the function are chosen so that the sum of squares of deviations of experimental (empiric) values $Y_{i}$ from their estimated (theoretical) values $Y_{i p}$ should be minimal, that is:

$$
S=\sum_{i=1}^{n}\left(Y_{\dot{p}}-Y_{i}\right)^{2}=\sum_{i=1}^{n}\left(Y-\phi\left(X, b_{0}, b_{1 R} \ldots, b\right)\right)^{2} \rightarrow \min .
$$

The resulting equations with calculated coefficients take the form:
- first-grade sausages

$$
\begin{aligned}
& Z=0.0029-0.00001 X-0.000002 X^{2}- \\
& -0.000023 Y-0.000001 Y^{2}+0.0000047 X Y
\end{aligned}
$$

- top-grade sausages

$$
\begin{aligned}
& Z=0.0027-0.000003 X-0.0000014 X^{2}- \\
& -0.000082 Y-0.0000047 Y^{2}+0.0000021 X Y .
\end{aligned}
$$

The resulting graphical 3D models take the form shown in Fig. 2 for equation (5) and in Fig. 3 for equation (4).

The presented 3D models indicate that the values of the PV, increase during the storage at a decrease in the fraction of residual nitrite.

Estimation of the error of approximating polynomials (4) and (5) was carried out from the following formula:

$$
\sigma=\sqrt{\frac{\sum_{i=1}^{n}\left(y_{i}-\hat{y}_{i}\right)^{2}}{n-1}},
$$

where $\hat{y}_{i}$ is the values calculated with the help of a regression equation, $y_{i}$ is the values of the experimental data.

For the indicator of residual content of sodium nitrite of pasteurized top-grade sausages, root mean square deviation is $\sigma=0.00002, \mathrm{mMol} \mathrm{AK}$, for the indicator of residual content of sodium nitrite of pasteurized first-grade sausages, it is $\sigma=0.00001, \mathrm{mMol} \mathrm{AK}$, which indicates a rather high degree of research results reproducibility with the help of the response area.

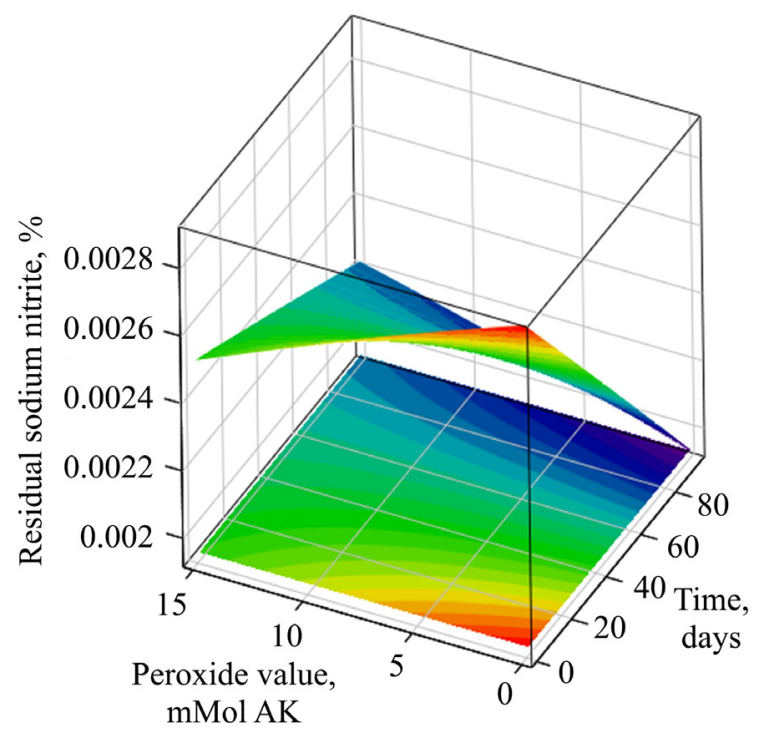

Fig. 2. Dependence between residual content of sodium nitrite and the PV in storage period for pasteurized topgrade sausages 


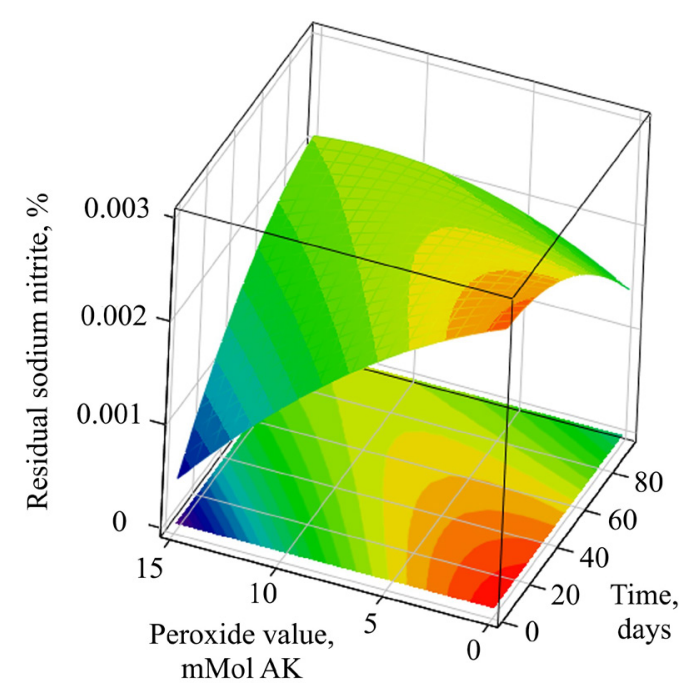

Fig. 3. Dependence between residual content of sodium nitrite and the PV in storage period for pasteurized firstgrade sausages
5. 2. Influence of pasteurization on indicators of the PV of sausage products during long-term storage

According to the experimental data, we obtained the dependences of the kinetics of a change in the PV of pasteurized top grade and first grade sausages, which are shown in Fig. 4, 5.

A decrease in the grade of sausages increases the rate of PV accumulation. At the same time, within the samples of equal grades, the highest PV values were observed during the storage of non-pasteurized samples. The use of an oxygen absorber during pasteurization increases the PV more quickly compared to pasteurized sausages without the use of oxygen absorber up to 35 days of storage. However, after that, a change in the PV stabilizes and is better than that of non-pasteurized sausages. In this case, first-grade sausages pasteurized with an oxygen absorber reach the boundary $\mathrm{PV}$ values, which corresponds to $10 \mathrm{mMol} \mathrm{AK}$, on day 83 of storage, those pasteurized without an absorber - on day 95 . The top-grade sausages pasteurized with or without an oxygen absorber did not achieve the critical PV even on day 95 of storage.

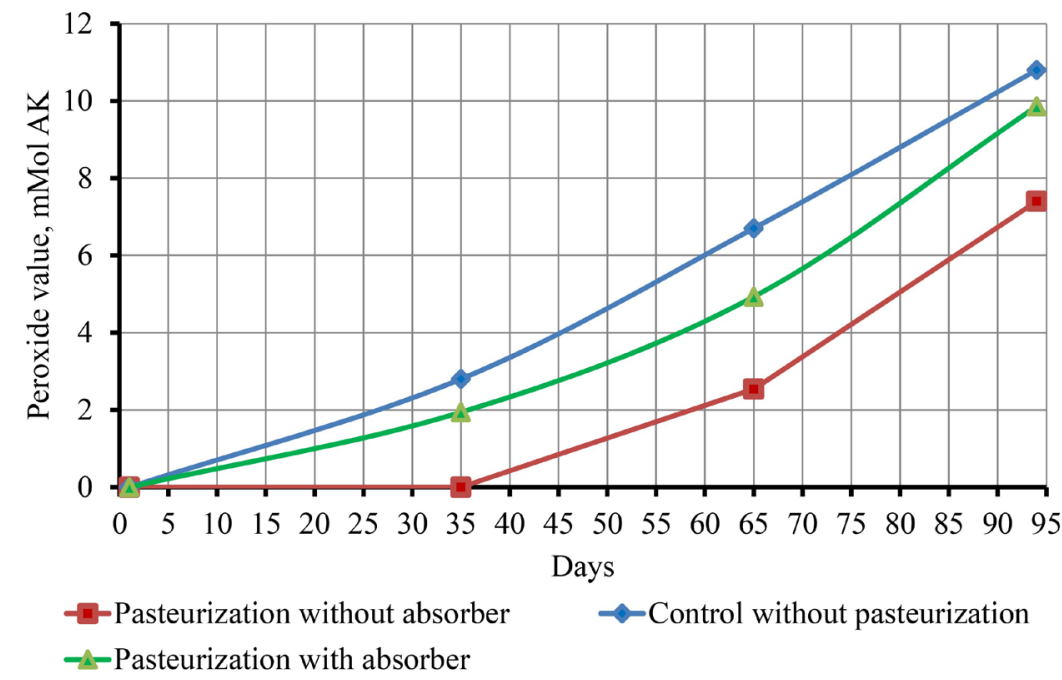

Fig. 4. The kinetics of a change in the PV of pasteurized top-grade sausages in the process of storage

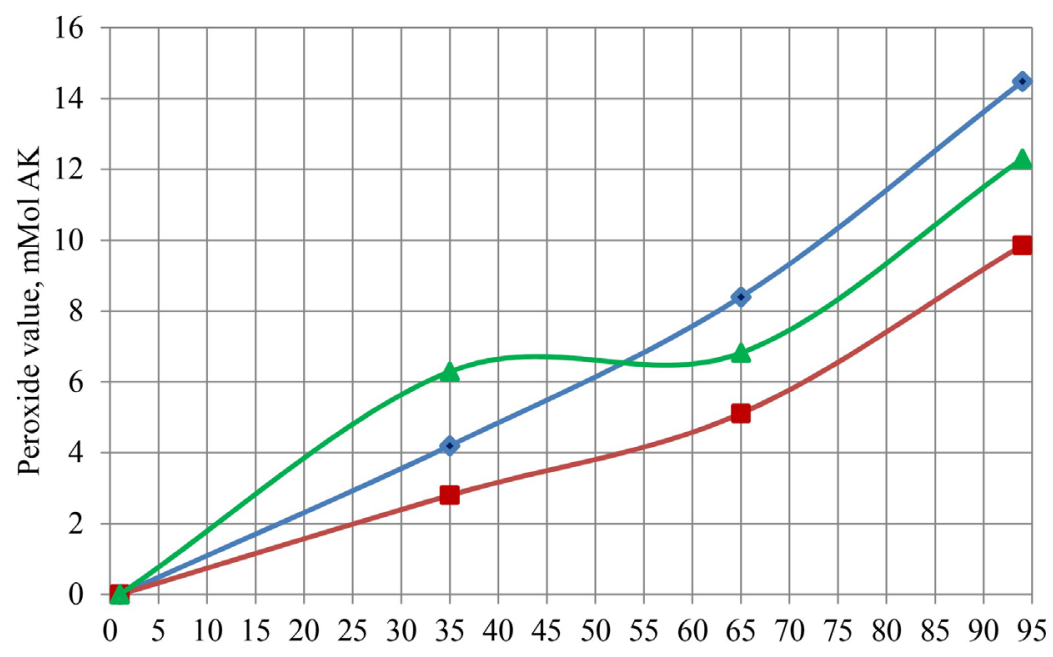

Fig. 5. The kinetics of changes in the PV of pasteurized first-grade sausages during storage 
That is why the determining factor of increasing the PV in the storage process is the absence of pasteurization and a decrease in the grade of sausage products.

5. 3. Influence of pasteurization on the AV of sausage products during the long-term storage

The study of the AV of sausages of different grades pasteurized with or without an absorber in the process of storage made it possible to obtain dependences describing the process of its change, depending on a pasteurization method.

The resulting equations with calculated coefficients are as follows:

- AV $\left(Y_{1}\right)$ for first-grade sausages pasteurized without an oxygen absorber is described by equation (7):

$$
Y_{1}=-0.0116+0.0992 t, R^{2}=0.9973
$$

- AV $\left(Y_{1}\right)$ for first-grade sausages pasteurized with an oxygen absorber is described by equation (8):

$$
Y_{1}=0.3656+0.1228 t, R^{2}=0.9899 .
$$

The kinetics of change in the AV in the process of storage of first grade sausages is shown in Fig. 6 .

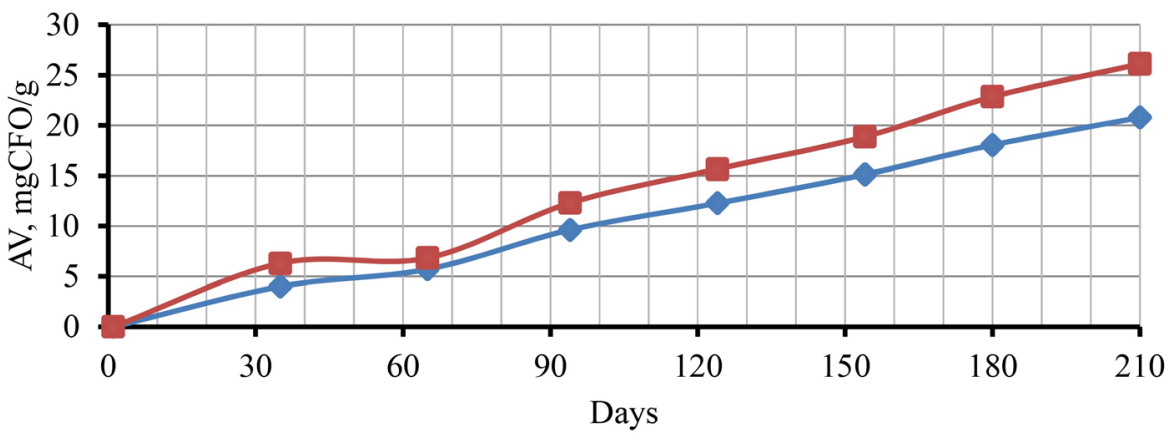

\section{-Pasteurization without an oxygen absorber. Prediction \\ -Pasteurization with an oxygen absorber. Prediction}

Fig. 6. The kinetics of change in AV of pasteurized first-grade sausages in the storage process

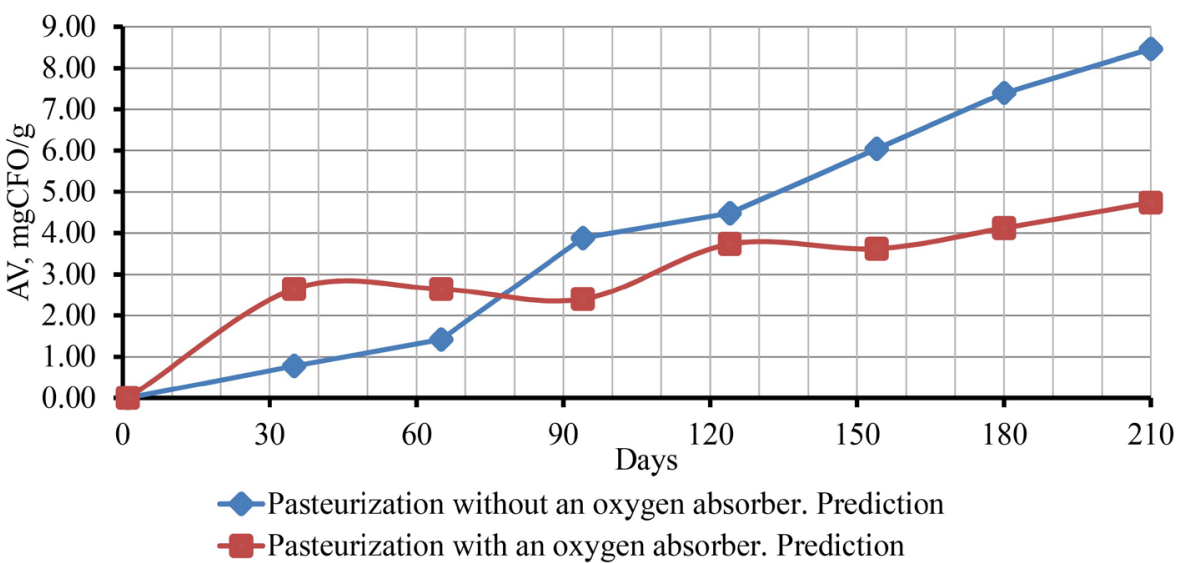

Fig. 7. The kinetics of change in the $\mathrm{AV}$ of pasteurized top-grade sausages in the process of storage
$\mathrm{AV}\left(Y_{1}\right)$ for top-grade sausages pasteurized without an oxygen absorber is described by equation (9).

$$
Y_{1}=-0.5684+0.0429 t, R^{2}=0.9819 \text {. }
$$

$\mathrm{AV}\left(Y_{1}\right)$ for top-grade sausages pasteurized with an oxygen absorber is described by equation (10).

$$
Y_{1}=1.0236+0.0182 t, R^{2}=0.9221 \text {. }
$$

The kinetics of change in the AV during the storage of

Changes in the AV of pasteurized sausages more intensively occur for first-grade products and effective use of oxygen absorber to slow down an increase in the AV is wen using high quality raw materials in formuion composition. It allows predicting the potential shelf $\mathrm{KOH} / \mathrm{g}$ of product, and for top-grade sausage products for more than 210 days.

5. 4. Influence of pasteurization on the MAFAM values of sausage products during a longterm storage

The dependences of changes in the PV and the $\mathrm{AV}$ in the process of storage of pasteurized sausages of different grades are correlated with a change in the values of MAFAM of these products.

Fig. 8, 9 show a change in the MAFAM indicators of pasteurized top grade and firstgrade sausages with or without the use of an oxygen absorber during the storage.

The presented dependences of changes in the MAFAM values during storage up to day 95 indicate the compliance with safety requirements of pasteurized sausages with or without using an oxygen absorber. At the same time, in the case of using an oxygen absorber for high grade products, the stabilization of the MAFAM values in dynamics is better than for the first-grade sausages.

For pasteurized first grade sausages, the use of an oxygen absorber makes it possible to prevent more effectively the growth of microflora up to day 65 of storage. At a longer shelf life, the dynamics of microflora growth is more intense, which is consistent with the deterioration of the PV and the AV of firstgrade products. 


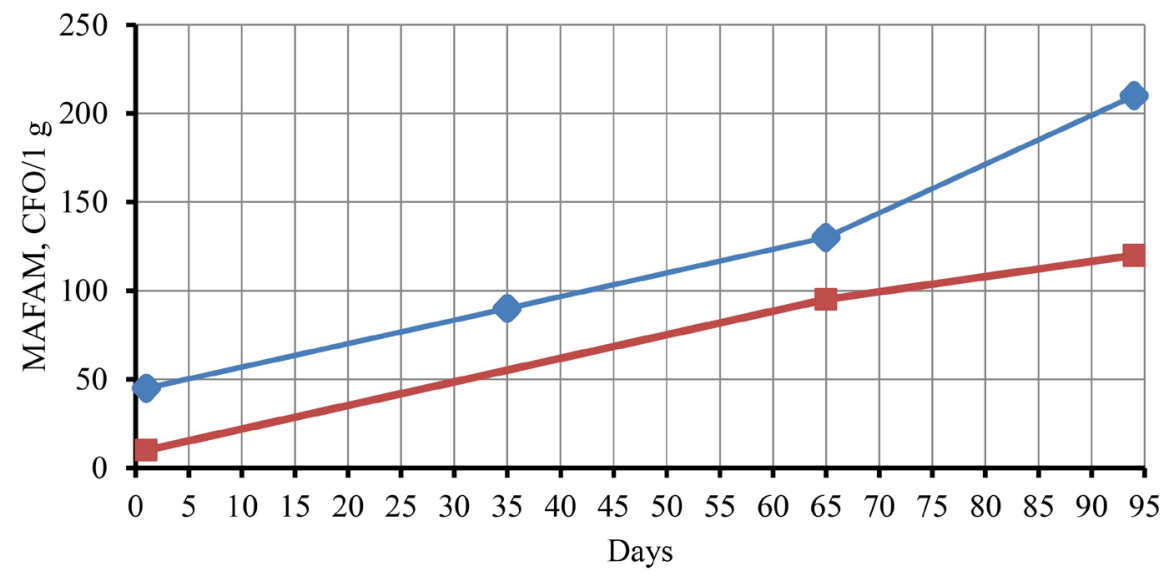

Pasteurization without an absorber

- -Pasteurization with an absorber

Fig. 8. The kinetics of change in the MAFAM of pasteurized top grade sausages

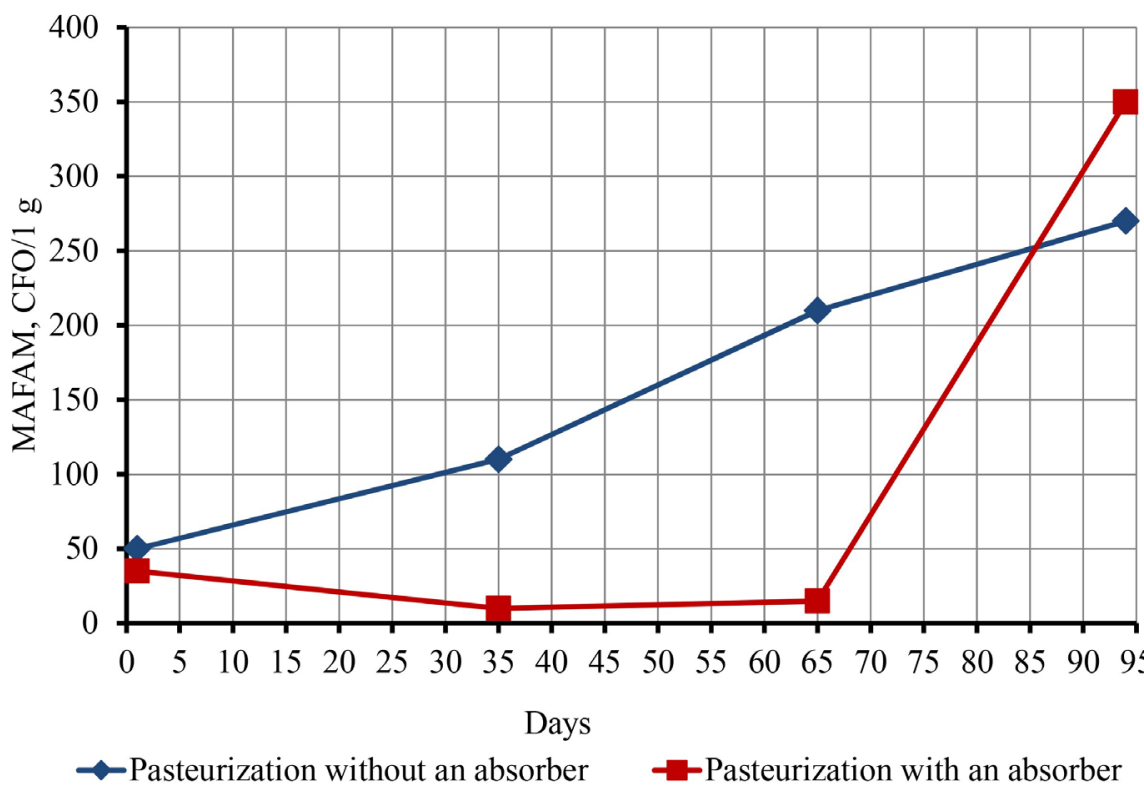

Fig. 9. Kinetics of a change in the MAFAM of first grade pasteurized sausages this case, pasteurized first-grade sausages reach the critical safety values of the PV when using an oxygen absorber on day 83 (Fig. 5). The critical PV value is reached on storage day 95 without the use of an oxygen absorber.

For pasteurized top-grade sausages, both with and without the use of an oxygen absorber, the values of spoilage by the PV and AV indicators were not reached until storage day 95 (Fig. 4, 7).

The boundary values, characterizing product spoilage by the MAFAM value for top-grade sausages also met safety requirements within 95 storage days (Fig. 8). In this case, top-grade sausage products, pasteurized with an oxygen absorber, have more stable values of the MAFAM in the process of long-term storage (Fig. 8) than the first-grade sausages (Fig. 9). This makes it possible to reach potentially much longer shelf life than 95 days during pasteurization with an oxygen absorber.

This proves the effectiveness of re-pasteurization to ensure the level of microbiological stability of boiled sausages on the example of sausages using an oxygen absorber.

The mathematical dependences and parametrization of safety indicators of sausages of different grades pasteurized with the use of an oxygen absorber with the shelf life of more than the normatively regulated period of 45 days were obtained. This makes it possible to predict reliably the shelf life of up to 83 days for pasteurized boiled first-grade sausage products by the value of the PV indicator. For pasteurized boiled top-grade sausage products, it is up to 95 days.

However, to ensure the stability of boiled sausage products using re-pasteurization with an oxygen absorber in a longer range of storage terms, it is necessary to search for the ways to increase the antioxidant potential of products.

In order to counteract the spoilage of fats of boiled sausage products of extended shelf life with the use of oxygen absorbers in the pasteurization process, it is necessary to conduct further search studies regarding effective natural antioxidants. The extracts of rosemary [35,38], oregano [36, 40], extract of grape pits [39], which are used in the production of boiled sausages, can be used as antioxidants. In addition, to enhance the anti-oxidant potential of meat raw material [37, 41], an effective result may be the search for the ways to enhance the thermal stability of antioxidants and minimize the pasteurization time [42].

Further research will be directed to identification of natural antioxidants- synergists regarding the elements of 
active packaging of sausage products and prediction of their influence on quality and safety indicators of pasteurized sausages of the boiled group.

\section{Conclusions}

1. A decrease in the residual content of sodium nitrite in the process of extended storage of pasteurized boiled sausage products and the relation between a decrease in the content of sodium nitrite in accordance with the values of peroxide number of products were determined. This makes it possible to predict the beginning of spoilage processes in first-grade sausage products at re-pasteurization starting from storage day 65 .

2. The use of pasteurization with an oxygen absorber accelerates the PV accumulation compared with pasteurization without an oxygen absorber. For first grade sausages, the PV value limits the shelf life of pasteurized sausages up to 83 days. For top-grade sausages pasteurized with an oxygen absorber, the shelf life is limited to 95 days by the PV indicator.

3. It was found that changes in the AV of pasteurized sausages more intensively occur in first-grade products and it is actually effective to use an oxygen absorber to slow down an increase in the $\mathrm{AV}$, which is possible when using high quality raw materials as a part of formulations. Estimated critical spoilage time according to the AV indicator for first-grade sausages is 120 days, and that for top-grade sausages is 210 days.

4. It was determined that the use of an oxygen absorber during pasteurization for both top grade and first-grade sausages increases the microbiological stability of products. This makes it possible to recommend, taking into account the MAFAM indicator, the shelf life that is longer than 95 days during the storage of boiled sausage products pasteurized with an oxygen absorber.

\section{Acknowledgements}

The study was supported by the grants of the Ministry of Education and Science of Ukraine "Scientific and practical substantiation of technologies for meat and meat-containing products of extended shelf life" No. $0118 \mathrm{U} 003557$ and "Scientific substantiation and development of active package systems of food stuffs" No. 0118U003558.

\section{References}

1. Ukrainets, A., Pasichniy, V., Zheludenko, Y., Polumbryk, M. (2016). Impact of protein composition with collagen on boiled sausages quality. Food Science and Technology, 10 (3), 50-55. doi: https://doi.org/10.15673/fst.v10i3.181

2. Pasichniy, V., Khomenko, Y., Polumbryk, M. (2014). Using of polymers as carriers in encapsulation of spice oleoresins. Ukrainian Journal of Food Science, 2 (2), 213-219.

3. Pasichnyi, V., KhrapachovO., Ukrainets, A., MaryninA., Lohvynenko, N., Kapitula, E. (2018). Use of repeated pasteurization for the production of boiled sausage products. Scientific Messenger of LNU of Veterinary Medicine and Biotechnologies. Series: Food Technologies, 20 (85), 29-34. doi: https://doi.org/10.15421/nvlvet8506

4. Pasichnyi, V., Ukrainets, A., Khrapachov, O., Marynin, A. (2018). Main aspects of using multilayer polymeric materials for pasterization and sterilization of products in the meat processing industry. Scientific Works of National University of Food Technologies, 24 (4), 195-203. doi: https://doi.org/10.24263/2225-2924-2018-24-4-22

5. Robertson, G. L. (2012). Food Packaging. Principles and Practice. CRC Press, 20-42.

6. Lee, J. J., Kim, D. H., Lim, J. J., Kim, D. G. et. al. (2011). Sterilization effects of avian influenza virus and newcastle disease virus in chicken muscle and organs dependent on autoclaving time. Korean Journal of Veterinary Public Health, 35 (4), 270-274. Available at: https://agris.fao.org/agris-search/search.do?recordID=KR2012004468

7. Silva, F. V. M., Gibbs, P. A. (2012). Thermal pasteurization requirements for the inactivation of Salmonella in foods. Food Research International, 45 (2), 695-699. doi: https://doi.org/10.1016/j.foodres.2011.06.018

8. Bal'-Prilipko, L. V., Zadorozhniy, V. I., Onishchenko, L. V. (2006). Vliyanie razlichnyh faktorov na srok i kachestvo hraneniya myasnyh produktov. Myasnoe delo, 8, 53-55.

9. Shahidi, F. (Ed.) (1997). Natural Antioxidants. Chemistry. Health Effects and Applications. Champaign: AOCS Press, 432.

10. Ukrainets, A., Pasichniy, V., Zheludenko, Yu. (2016). Antioxidant plant extracts in the meat processing industry. Biotechnologia Acta, 9 (2), 19-27. doi: https://doi.org/10.15407/biotech9.02.019

11. Ukrainets, A., Pasichyi, V., Zheludenko, Yu., Zadkova, S. (2016). Oleoresins effect on cooked poultry sausages microbiological stability. Ukrainian Food Journal, 5 (1), 124-134. Available at: http://dspace.nuft.edu.ua/jspui/bitstream/123456789/30428/4/5.pdf

12. McBride, N. T. M., Hogan, S. A., Kerry, J. P. (2007). Comparative addition of rosemary extract and additives on sensory and antioxidant properties of retail packaged beef. International Journal of Food Science \& Technology, 42 (10), 1201-1207. doi: https:// doi.org/10.1111/j.1365-2621.2006.01342.x

13. Bozhko, N., Tischenko, V., Pasichnyi, V., Marynin, A., Polumbryk, M. (2017). Analysis of the influence of rosemary and grape seed extracts on oxidation the lipids of peking duck meat. Eastern-European Journal of Enterprise Technologies, 4 (11 (88)), 4-9. doi: https://doi.org/10.15587/1729-4061.2017.108851

14. Pasichniy, V., Geredchuk, A., Moroz, O., Yastreba, Yu. (2015). Investigation of the factors of shelf-life prolongation for meat and meat-containing products. Naukovi pratsi Natsionalnoho universytetu kharchovykh tekhnolohiy, 21 (4), 224-230. Available at: http://dspace.puet.edu.ua/handle/123456789/7593

15. Dixon, J. (2011). Packaging materials 9: multilayer packaging for food and beverages. ILSI Europe Report Series, 1-43.

16. Vinnikova, L., Prokopenko, I. (2015). The application of high pressure as an alternative to thermal processing of poultry meat. Eastern-European Journal of Enterprise Technologies, 3 (10 (75)), 31-36. doi: https://doi.org/10.15587/1729-4061.2015.44241

17. Vinnikova, L. G., Pronkina, K. V. (2016). The changes of characteristics of the pork whole muscle meat products while using the electrolyzed water. Food Science and Technology, 10 (2), 19-23. doi: https://doi.org/10.15673/fst.v10i2.151 
18. Mohammed, H. N. (2013). Study of some chemical, physical, sensory and bacteriology characteristics of canned chicken meat imported to Sulaymaniyah markets. International Journal of nutrition and Metabolism, 5 (7), 128-133. Available at: https://academicjournals.org/article/article1379686298_Mohammed.pdf

19. Bozhko, N., Tischenko, V., Pasichnyi, V., Polumbryk, M., Haschuk, O. (2018). Development of meat-containing minced semi-finished products based on the locally produced raw materials. Eastern-European Journal of Enterprise Technologies, 4 (11 (94)), 49-54. doi: https://doi.org/10.15587/1729-4061.2018.140052

20. Rynok miasa ptytsi v Ukraini (2017). Available at: http://www.poultryukraine.com/data/file/analytics/ptica_yanvar_maj_2017.pdf

21. Svyatnenko, R., Marynin, A., Makogon, A., Fursik, O. (2017). Influence of pulsed electric fields on microbiological indices and content of vitamin C in whole milk. Scientific Messenger of LNU of Veterinary Medicine and Biotechnologies. Series: Food Technologies, 19 (80), 29-32. doi: https://doi.org/10.15421/nvlvet8006

22. Ukrainets, A., Kochubei-Lytvynenko, O., Bilyk, O., Zacharevich, V., Vasilchenko, T. (2016). A study of the effect of enriched whey powder on the quality of a special-purpose bread. Eastern-European Journal of Enterprise Technologies, 2 (11 (80)), 32-41. doi: https://doi.org/10.15587/1729-4061.2016.65778

23. Pasichniy, V., Marynin, A., Moroz, E., Geredchuk, A. (2015). Development of combined protein-fat emulsions for sausage and semifinished products with poultry meat. Eastern-European Journal of Enterprise Technologies, 1 (6 (73)), 32-38. doi: https:// doi.org/10.15587/1729-4061.2015.36232

24. Kishenko, I., Kryzhova, Y., Filonenko, M. (2016). Research of fermented compound transglutaminase on the model samples of restrustured beef ham. Scientific Messenger of LNU of Veterinary Medicine and Biotechnologies. Series: Food Technologies, 18 (2), 46-50. doi: https://doi.org/10.15421/nvlvet6809

25. Shubina, G. (2015). Vydelenie vlagi v upakovkah gotovyh myasnyh produktov: prichiny i puti resheniya problemy. Myasnoy biznes, $2,26-28$

26. Usatenko, N. F., Kryzhska, T. A. (2012). Zberihannia ta pererobka produktsiyi. Vykorystannia pokaznyka «aktyvnist vody» v tekhnolohii vyrobnytstva miasoproduktiv. Visnyk ahrarnoi nauky, 5, 62-65.

27. Benderska, O., Levkivska, T., Bessarab, A. (2018). Technological aspects of "water activity" indicator and its influence on the quality of tomato souss. International Scientific Journal "Internauka", 2 (50), 11-14.

28. TU U 15.1-31923621-002:2010. Vyroby kovbasni vareni, sosysky, sardelky, zapakovani pid vakuumom v polimerni bahatosharovi materialy «Kriovak» («CRYOVAC») pasteryzovani.

29. TU U 563/46.05407953.60-98. Vyroby kovbasni ta kopchenosti miasni, zapakovani pid vakuumom v polimerni plivkovi bahatosharovi termozsidalni materialy «Kriovak» («CRYOVAC»).

30. Antipova, L. V., Glotova, I. A., Rogov, I. A. (2001). Metody issledovaniya myasa i myasnyh produktov. Moscow: Kolos, 576.

31. Pasichnyi, V., Ukrainets, A., Ukrainets, A., Khrapachov, O., Khrapachov, O., Marynin, A., Moroz, O. (2018). Research into efficiency of pasterization of boiled sausage products in order to improve their storage term. Eastern-European Journal of Enterprise Technologies, 6 (11 (96)), 21-28. doi: https://doi.org/10.15587/1729-4061.2018.147946

32. DSTU 8446:2015. Produkty kharchovi. Metody vyznachennia kilkosti mezofilnykh aerobnykh ta fakultatyvno-anaerobnykh mikroorhanizmiv. Kyiv.

33. DSTU ISO 4833:2006. Horyzontalnyi metod pidrakhunku mikroorhanizmiv. Tekhnika pidrakhuvannia kolonii za temperatury $30^{\circ} \mathrm{C}$ (ISO 4833:2003, IDT). Kyiv, 11.

34. Pasichnyi, V., Shevchenko, O., Khrapachov, O., Marynin, A., Radzievskaya, I., Matsuk, Y. et. al. (2020). Prognostication of storage terms for pasteurized sausages with active package elements. EUREKA: Life Sciences, 4, 34-43. doi: https://doi.org/10.21303/ 2504-5695.2020.001376

35. Ahn, J., Grun, I., Mustapha, A. (2007). Effects of plant extracts on microbial growth, color change, and lipid oxidation in cooked beef. Food Microbiology, 24 (1), 7-14. doi: https://doi.org/10.1016/j.fm.2006.04.006

36. Fasseas, M. K., Mountzouris, K. C., Tarantilis, P. A., Polissiou, M., Zervas, G. (2008). Antioxidant activity in meat treated with oregano and sage essential oils. Food Chemistry, 106 (3), 1188-1194. doi: https://doi.org/10.1016/j.foodchem.2007.07.060

37. Moyo, B., Oyedemi, S., Masika, P. J., Muchenje, V. (2012). Polyphenolic content and antioxidant properties of Moringa oleifera leaf extracts and enzymatic activity of liver from goats supplemented with Moringa oleifera leaves/sunflower seed cake. Meat Science, 91 (4), 441-447. doi: https://doi.org/10.1016/j.meatsci.2012.02.029

38. Carpenter, R., O'Grady, M. N., O'Callaghan, Y. C., O'Brien, N. M., Kerry, J. P. (2007). Evaluation of the antioxidant potential of grape seed and bearberry extracts in raw and cooked pork. Meat Science, 76 (4), 604-610. doi: https://doi.org/10.1016/ j.meatsci.2007.01.021

39. Doolaege, E. H. A., Vossen, E., Raes, K., De Meulenaer, B., Verh, R., Paelinck, H., De Smet, S. (2012). Effect of rosemary extract dose on lipid oxidation, colour stability and antioxidant concentrations, in reduced nitrite liver pâtés. Meat Science, 90 (4), 925-931. doi: https://doi.org/10.1016/j.meatsci.2011.11.034

40. Umaraw, P., Chauhan, G., Mendiratta, S. K., Verma, A. K Arya, A. (2020). Effect of oregano and bay as natural preservatives in meat bread for extension of storage stability at ambient temperature. Journal of Food Processing and Preservation, 44 (4). doi: https:// doi.org/10.1111/jfpp.14375

41. Masoodi, F. A. (2016). Advances in use of natural antioxidants as food additives for improving the oxidative stability of meat Products. Madridge Journal of Food Technology, 1 (1), 10-17. doi: https://doi.org/10.18689/mjft-1000102

42. Vinnikova, L., Synytsia, O., Shlapak, H., Azarova, N., Glushkov, O. (2019). Establishing temperature and time factors for the post-pasteurization of gourmet meat products. Eastern-European Journal of Enterprise Technologies, 5 (11 (101)), 33-39. doi: https://doi.org/10.15587/1729-4061.2019.178410 